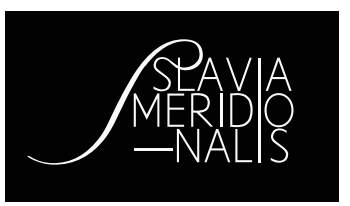

\title{
Artur Karasiński
}

Katedra Bałkanistyki

Uniwersytet Mikołaja Kopernika w Toruniu

\section{Zanikanie bezokolicznika w języku serbskim. Wstępne rozpoznanie zagadnienia}

Tendencja do zanikania bezokolicznika (częściowej bądź całkowitej utraty tej formy językowej) w językach należących do Bałkańskiej Ligi Językowej została zauważona i udokumentowana już w podstawowych pozycjach dotyczących bałkanologii (Sandfeld, 1930; Schaller, 1975). Szczegółowo o procesach konwergencyjnych dotyczących zanikania bezokolicznika pisze przede wszystkim Joseph Brian (1980, 1981, 1983), Petya Assenova (Асенова, 2002). Demiraj (1970) zaś opisuje proces zaniku albańskiego bezokolicznika.

Język serbski nie utracił ostatecznie bezokolicznika, wręcz w niektórych kontekstach konstrukcja $\mathrm{z}$ nieosobową formą czasownika jest obligatoryjna. Szczegółowo zagadnienie bezokolicznika w języku serbskim poruszają M. Ivić (1972), D. Zvekić-Dušanović (2001), B. Belić (2005).

Milka Ivić zauważa, że wschodnie narzecze języka serbsko-chorwackiego nazwano symbolicznie „dakawskim”, gdyż w nim znacznie częściej używana jest tzw. konstrukcja z $d a$ w dopełnieniowych zdaniach polipredykatywnych,

This work was supported by the Polish Ministry of Science and Higher Education.

Competing interests: no competing interests have been declared.

Publisher: Institute of Slavic Studies PAS.

This is an Open Access article distributed under the terms of the Creative Commons Attribution 3.0 PL License (creativecommons.org/licenses/by/3.0/pl/), which permits redistribution, commercial and non-commercial, provided that the article is properly cited. (c) The Author(s) 2015. 
niż ma to miejsce na zachodzie sztokawskiego obszaru językowego. Nie znaczy to jednak, że na wschodzie użycie bezokolicznika jest wykluczone. Petya Assenova odnośnie zastępowania bezokolicznika konstrukcją analityczną w języku serbsko-chorwackim także zwraca uwagę na podział geograficzny (za Lj. Popoviciem), podobnie jak w przypadku języka albańskiego. Zauważa, że im dalej na północ (w przypadku albańskiego), tak i (w przypadku dialektów słowiańskich) na północny i południowy zachód od centrum pełnego lub prawie pełnego zastąpienia bezokolicznika konstrukcją analityczną, czyli od geograficznych terenów języków greckiego, bułgarskiego i arumuńskiego, tym częstsze jest użycie bezokolicznika. Zanik bezokolicznika w serbsko-chorwackim jest więc stopniowo coraz mniejszy, idąc od południa i wschodu, aż do północnego і zachodniego narzecza serbsko-chorwackiego (Асенова, 2002, ss. 148-149). Dziś, mając na względzie rozdział języka serbsko-chorwackiego na język serbski, chorwacki, bośniacki i czarnogórski oraz fakt, że język serbski funkcjonujący w Bośni jest strukturalnie tożsamy z językiem bośniackim, należy stwierdzić, że proces zaniku bezokolicznika jest najbardziej zaawansowany w serbskim i czarnogórskim, a na terytorium samej Serbii w dialektach wschodnich i południowych: w prizrensko-tymockim zanik jest już kompletny, w kosowsko-resawskim i smederewsko-wyrszackim - prawie kompletny, w szumadijskim zastępowanie bezokolicznika konstrukcją analityczną jest zaawansowane i zalecane w formie literackiej. Dialekty północno-zachodnie ze starą fleksją zastępują bezokolicznik w niewielkim stopniu. W chorwackim omawiane zjawisko nie występuje w ogóle.

Problem jest zatem dość dobrze udokumentowany i poparty badaniami już od czasu, kiedy powstała geografia lingwistyczna. Temat jest aktualny także ze względu na politykę językową prowadzoną na Bałkanach (zarówno z czasach Jugosławii, jak i - zwłaszcza - po jej rozpadzie).

Artykuł dotyczy procesu zaniku bezokolicznika w języku serbskim i stopniowego zastępowania bezokolicznika konstrukcją $d a+$ praesens. Materiał, jaki posłużył do tej sondażowej analizy, stanowi przekrój piśmiennictwa ograniczonego do rdzennych terenów serbskich: wychodzi już od czasów św. Sawy, którego teksty jako jedne z pierwszych są powszechnie dostępne. Analizie poddano 13 utworów literackich. Kilka $z$ tych pozycji to dzieła zebrane.

Artykuł analizuje wariantywność form bezokolicznika i konstrukcji $d a+$ praesens w języku serbskim w toku rozwoju literatury serbskiej, od początków literatury pisanej do dziś. Punktem wyjścia w badaniu jest syntaktyczny kontekst bezokolicznika i częstotliwość zastępowania go na przestrzeni czasowej, 
dzielącej ukazanie się przebadanych dzieł literatury serbskiej, przez konstrukcję składniową ze spójnikiem $d a+$ praesens. Aby analiza częstości występowania konstrukcji składniowych z bezokolicznikiem i równoznacznych konstrukcji wyrażeń ze spójnikiem da i czasownikiem osobowym w czasie teraźniejszym w poszczególnych pozycjach literatury serbskiej, i następnie porównanie wyników w przekroju diachronicznym, miały sens, trzeba do niej włączyć jedynie konteksty, gdzie wciąż możliwa jest dystrybucja fakultatywna tych dwóch konstrukcji czasownikowych. Należy bowiem pamiętać, że wariantywność obu konstrukcji w standardzie języka serbskiego nie jest nieograniczona. Występują w języku serbskim takie konstrukcje składniowe, które nie dopuszczają fakultatywnych użyć, a zatem bezokolicznik i konstrukcja $\mathrm{z} d a+$ praesens znajdują się częściowo w stosunku dystrybucji komplementarnej. O interpretacji semantycznej może czasem decydować rodzaj dystrybucji, ale też w znacznej mierze zależności semantyczne wypowiedzi. Weźmy np. zdania: Neću da dođem / Neću doći. Kontekst leksykalny jest taki sam - konstrukcje występują po krótkiej formie modalnego czasownika hteti + negacja. W drugim przypadku mamy do czynienia z zaprzeczeniem czasu przyszłego, natomiast pierwsze zdanie może być także interpretowane jako konstrukcja wolitywna. $Z$ tego względu kontekst zdań w czasie przyszłym (futur I) został w badaniu pominięty, gdyż wymaga głębszej analizy w strukturze predykatowo-argumentowej, a jego interpretacja wymaga uwzględnienia szerokiego kontekstu. Materiał został więc przebadany w kontekstach, w których obie konstrukcje są w pełni równoznaczne. Warunkiem koniecznym do wystąpienia wariantywności tych dwu konstrukcji jest koreferencja podmiotu zdania podrzędnego i podmiotu lub dopełnienia zdania głównego (Polański, 2003, s. 225).

Zasadniczy kontekst, jaki został uwzględniony w badaniu i stanowi jego większą część, to wymienność konstrukcji po czasownikach modalnych: moći, trebati, morati i hteti. Badanie uwzględnia wszystkie przykłady zdań we wszystkich możliwych formach czasowych i osobowych tych czasowników modalnych. Jedynym wyjątkiem jest tu modalny czasownik trebati, który w konstrukcji polipredykatywnej występuje w standardzie w bezosobowych formach (dla czasu teraźniejszego treba, dla przeszłego trebalo je) (zob. Брборић, Ивић, Клајн, Пешикан, 2007, 148-150).

Drugi przebadany kontekst to występowanie bezokolicznika i konstrukcji $d a+$ praesens po czasownikach wymagających uzupełnienia semantycznego takich jak: želeti, smeti, umeti. Kolejne konteksty stanowią czasowniki fazowe, oznaczające początek, przerwanie lub kontynuowanie jakiejś czynności. 
Klasyfikację kończy kontekst czasowników ruchu, po których występuje dopełnienie oznaczające zamiar dokonania jakiejś czynności czy zmiany stanu. Uwzględniono różne formy czasowe i osobowe czasownika nadrzędnego w wyżej wymienionych kontekstach.

Materiał badawczy stanowi pewien przekrój literatury serbskiej, jednak w granicach, jakie umożliwia wybór tekstów pretendujących do miana języka ogólnego. Ograniczenia, czy raczej utrudnienia we wnioskowaniu, mogą wynikać z faktu, że autorzy posługujący się językiem ogólnym, pochodzą $\mathrm{z}$ różnych regionów, reprezentujących różne stadia omawianego procesu. Początki piśmiennictwa serbskiego są dosyć wczesne i wiążą się z rozwojem serbskiej redakcji języka staro-cerkiewno-słowiańskiego. Za czas kształtowania się redakcji serbskiej przyjmuje się wiek XII. Jednocześnie przez cały okres średniowiecza w Serbii w mowie używany jest język staroserbski, który w formie pisanej występował niezmiernie rzadko. Inaczej w Bośni czy w Chorwacji, gdzie współczesna forma językowa dosyć szybko weszła do piśmiennictwa i wyparła wersję cerkiewnosłowiańską. Średniowieczna literatura serbska jest silnie związana ze wzrostem znaczenia państwa Stefana Nemanji. Pierwszym tekstem przeanalizowanym pod kątem użycia bezokolicznika i konstrukcji $d a+$ praesens w wyżej wymienionych kontekstach jest zbiór Sveti Sava - Sabrana Dela (Dzieła Zebrane Świętego Sawy, 1175-1235), wydany w 2009 w Antologija Srpske Književnosti ${ }^{1}$. Mimo spodziewanych ograniczeń, wynikających z ówczesnej formy języka pisanego, do tekstów tych przedostało się sporo form ludowych, w tym konstrukcji da + praesens, co uzasadnia uwzględnienie tych tekstów w badaniu. Trudno jednak określić, czy niewielka liczba tych form wynika ze wskazanych ograniczeń, czy ze słabego zaawansowania procesu zaniku w tym czasie - jest to bowiem okres, w którym kształtują się słowiańskie bałkanizmy, a o początku procesu nie można sądzić wobec braku wcześniejszych tekstów. Istnieją jedynie niezbyt liczne teksty w języku demotycznym, na których podstawie możemy sądzić, że w języku greckim bezokolicznik ostatecznie zniknął w XIV/XV wieku (Лопашов, 1990).

Zbiór Sveti Sava - Sabrana Dela, liczący 105 stron, zawiera większość tekstów, jakie wyszły spod pióra jednej z najważniejszych postaci serbskiego państwa, literatury i Serbskiej Cerkwi Prawosławnej. Pierwszy serbski arcybiskup jest twórcą liturgicznych hymnów i początków serbskiego prawodawstwa, w tym pierwszych przepisów klasztornych oraz pierwszych praw kościelnych.

\footnotetext{
${ }^{1}$ W ramach projektu digitalizacji klasycznych dzieł literatury serbskiej (www.ask.rs).
} 
Analiza utworu wykazała, że w zdaniach po czasownikach modalnych moći, trebati, morati i hteti przeważa bezokolicznik. Na 174 zdania w 124 wystąpił bezokolicznik, co stanowi 71\% wszystkich użyć tego kontekstu. W 50 zdaniach, w których wystąpiła konstrukcja da + praesens, 35 to przykłady z czasownikiem modalnym trebati. Mała liczba przykładów pozostałych kontekstów nie pozwala na wykazanie znaczących różnic w stosowaniu obu konstrukcji. Po czasownikach o niepełnym znaczeniu želeti, smeti, umeti w 7 zdaniach wystąpił bezokolicznik, a w 5 konstrukcja $d a+$ praesens. W kontekście zdań z czasownikami fazowymi i czasownikami ruchu, w całym zbiorze wystąpiły jedynie 3 zdania z bezokolicznikiem.

W XVII i XVIII wieku literatura serbska, po okresie stagnacji, który nie był bezowocny, jeżeli chodzi o dzieła, znalazła się w nowej fazie dynamicznego rozwoju. Kolejny analizowany utwór to Život i priključenija Dositeja Obradovicia, prekursora serbskiej literatury świeckiej. Przeanalizowano dwie części utworu, pierwszą wydaną w 1783 roku, drugą w 1788 roku. Utwory Dositeja Obradovicia powstały w języku slavenosrpskim, są więc obciążone tymi samymi, mutatis mutandis, ograniczeniami, co dzieła Sawy. Z drugiej jednak strony jednym ze składników języka slavenosrpskiego jest język ludowy - można się zatem spodziewać zaawansowania procesu. Analiza ukazuje jednak, że bezokolicznik nie jest zastępowany jeszcze przez konstrukcję da + praesens. Na 357 zdań z czasownikami modalnymi 348 to konstrukcje z bezokolicznikiem (97\%). Po želeti, smeti, umeti stwierdzono 21 zdań z bezokolicznikiem (co stanowi 65\%) i 11 $\mathrm{z} d a+$ praesens. $100 \%$ użyć bezokolicznika mamy po czasownikach fazowych (68 zdań). Podobnie po czasownikach ruchu (krenuti, ići) - 100\% (8 zdań).

Przeanalizowano także dzieło okresu wczesnego romantyzmu, Đury Jakšicia (1832-1878), głównego przedstawiciela prozy romantycznej. Przeanalizowano zbiór opowiadań zatytułowany Proza z 1849 roku. Utwór ten potwierdza jeszcze wysoką frekwencję bezokolicznika w zdaniach z czasownikami modalnymi. 149 przykładów $\mathrm{z}$ bezokolicznikiem w stosunku do 27 zdań z konstrukcją da + praesens stanowi $85 \%$ wystąpień bezokolicznika w tym kontekście. Po czasownikach o niepełnym znaczeniu želeti, smeti, umeti stosunek zdań z bezokolicznikiem do zdań z konstrukcją z da wynosi 12 do 5 . Zdań z czasownikami fazowymi wyekscerpowano tylko 6, we wszystkich wystąpił bezokolicznik. Po czasownikach ruchu wystąpiła dwukrotnie konstrukcja da + praesens i jeden raz bezokolicznik.

Kolejnym przedstawicielem prozy romantycznej w serbskiej literaturze, ale i pierwszym realistą jest Jakov Ignjatović (1822-1889). Urodził się w Sent Andreja, na Węgrzech, w serbskim miasteczku, które już od XVI wieku stanowiło centrum 
serbskiej diaspory na Węgrzech i jeden z ważniejszych punktów emigracyjnych serbskich intelektualistów. Analizie poddano powieść Večiti mladoženja (1878), traktującą o tradycjach kupieckich bogatej serbskiej rodziny na Węgrzech. Analiza utworu również potwierdziła przewagę bezokolicznika po czasownikach modalnych - 82\% (312 zdań z bezokolicznikiem na $67 \mathrm{z} d a+$ praesens). Wyraźna przewaga bezokolicznika występuje też po czasownikach o niepełnym znaczeniu želeti, smeti, umeti (15 zdań z bezokolicznikiem i tylko jedno $\mathrm{z} d a+$ praesens) i po czasownikach fazowych (34 przykłady wyłącznie z bezokolicznikiem). Jedynie po czasowniku ići wystąpiła wyłącznie konstrukcja osobowa $d a+$ praesens (11 zdań). Należy podkreślić, że mimo przewagi bezokolicznika i pochodzenia autora $\mathrm{z}$ tych serbskich terenów, które są najmniej zbałkanizowane, konstrukcje $\mathrm{z}$ da jednak wystąpiły dość licznie.

Za największego serbskiego realistę XIX stulecia uznaje się Lazę Lazarevicia (1851-1891), urodzonego w miejscowości Šabac. Większą część swego życia Lazarević spędził w Belgradzie. Analizie poddane zostały opowiadania Lazarevicia napisane w latach 1882-1890, zebrane i wydane w roku 2009 w Antologiji Srpske Književnosti. Na tom składa się siedem opowiadań (149 stron). W stosunku do poprzednio analizowanych tekstów badanie wykazało wzrost użycia konstrukcji osobowej z da po czasownikach modalnych, nadal jednak, z przewagą zdań $\mathrm{z}$ bezokolicznikiem - 64\% (153 zdania z bezokolicznikiem i 85 zdań z da + praesens). Największy wzrost odnotowano w pozycji po czasowniku hteti (60 zdań $\mathrm{z}$ da + praesens wobec $10 \mathrm{zdań} \mathrm{z}$ bezokolicznikiem). Po czasownikach želeti, smeti, umeti stosunek kształtuje się na korzyść bezokolicznika 20 (67\%) wobec 10 zdań z da + praesens. Podobnie po czasownikach fazowych - w 12 zdaniach wystąpił bezokolicznik, w $9 d a+$ praesens. Po czasowniku ići wystąpiła wyłącznie konstrukcja osobowa da + praesens - łącznie 4 zdania.

Pierwsza serbska proza modernistyczna wyszła spod pióra Borisava Stankovicia, który w wielu swoich utworach opisywał życie w swoim rodzimym mieście Vranje w południowej Serbii. Analizie poddano jego powieść Nečista krv (1910). Analiza tego utworu wykazuje już wyraźny spadek użycia bezokolicznika po czasownikach modalnych. W kontekście tym 86 razy wystąpił bezokolicznik, zaś w 209 zdaniach konstrukcja da + praesens, co czyni już tylko $29 \%$ użycia bezokolicznika po czasownikach modalnych. Także po želeti, smeti, umeti przewaga przykładów z konstrukcją osobową jest wyraźna ( 37 zdań z da + praesens, 10 - z bezokolicznikiem). W kontekście czasowników oznaczających rozpoczęcie bądź zakończenie jakiejś czynności lub stanu, także przewagę ma konstrukcja osobowa (53 zdania $\mathrm{z} d a+$ praesens 
i 19 z bezokolicznikiem). Po czasownikach ruchu odnotowałem tylko 6 przykładów - we wszystkich wystąpiła konstrukcja da + praesens. Odnotowany stosunek użyć obu konstrukcji potwierdziła także analiza zbioru opowiadań Božji Ljudi (1902) tego autora. Tu po czasownikach modalnych wystąpiła prawie wyłącznie konstrukcja osobowa $\mathrm{z} d a+$ praesens (40 zdań i tylko jedno zdanie z bezokolicznikiem, co czyni 2,4\%). W pozostałych kontekstach także występuje wyłącznie konstrukcja osobowa (po želeti, smeti umeti - 9 zdań, po czasownikach fazowych - 72, po czasownikach ruchu -6).

Tak częste użycie konstrukcji z da + praesens w utworach Stankovicia jest z pewnością pochodną jego miejsca urodzenia - Vranje leży na terytorium dialektu serbskiego, w którym współcześnie bezokolicznik w ogóle nie występuje.

Twórca serbskiej awangardy, ekspresjonista i główna postać modernistycznego belgradzkiego kręgu, Miloš Crnjanski i jego słynna powieść Seobe I, to kolejny analizowany tekst. Crnjanski urodził się w małym miasteczku węgierskim Čongrad w Banacie. Studiował w Wiedniu, potem trafił do Zagrzebia a w końcu do Belgradu, gdzie powstały jego główne dzieła. W latach 1940-1965 przebywał za granicą w służbie dyplomatycznej. Powieść Seobe („Wędrówki”) opublikowana została w 1929 roku.

Po czasownikach modalnych także u Crnjanskiego widzimy znaczny spadek użycia bezokolicznika. Bezokolicznik wystąpił w 32\% badanych kontekstów (86 zdań z użyciem bezokolicznika, 186 z konstrukcją $d a+$ praesens). Pozostałe konteksty też cechuje większe zastosowanie konstrukcji osobowej. W 10 zdaniach z czasownikami želeti, smeti, umeti wystąpiła wyłącznie konstrukcja z da + praesens i ani jeden bezokolicznik. Po czasownikach fazowych wystąpiło 36 zdań $\mathrm{z}$ konstrukcją $d a+$ praesens i $3 \mathrm{z}$ bezokolicznikiem, zaś po czterech zdaniach $\mathrm{z}$ czasownikami ruchu wystąpiła wyłącznie konstrukcja $d a+$ praesens.

Kolejne analizowane utwory wchodzą już w nurt nowego realizmu w serbskiej literaturze. Pierwszy z nich to powieść Na Drini ćuprija (1945) Ivo Andricia, pisarza urodzonego w miejscowości Travnik w Bośni. U Andricia podobnie jak u Crnjanskiego użycie bezokolicznika po czasownikach modalnych oscyluje w granicach $30 \%$ (324 zdań z konstrukcją $d a+$ praesens, 138 z bezokolicznikiem). W pozostałych kontekstach bezokolicznik praktycznie nie występuje. Po želeti, smeti, umeti - wystąpiło 50 zdań z da + praesens i tylko 2 zdania $\mathrm{z}$ bezokolicznikiem, po czasownikach fazowych 58 zdań wyłącznie z $d a+$ praesens, przykładów na kontekst po czasownikach ruchu nie znaleziono.

Następny tekst to Orlovi rano lete (1959) Branka Ćopicia, pisarza urodzonego w zachodniej Bośni, we wsi Hašani, u stóp góry Grmeč. Ćopić po studiach 
filozoficznych w Belgradzie pozostał w stolicy Jugosławii i tam tworzył wszystkie utwory. Analiza użycia bezokolicznika w badanych kontekstach wykazała, że autor relatywnie często korzysta $z$ konstrukcji bezosobowej - 70\% użycia czasownika po czasownikach modalnych to konstrukcje $\mathrm{z}$ bezokolicznikiem (76 zdań z bezokolicznikiem i $32 \mathrm{z}$ konstrukcją $d a+$ praesens). Pozostałe konteksty wykazują jednak częstsze użycie konstrukcji $d a+$ praesens (po czasownikach fazowych: $15 \mathrm{zdań} \mathrm{z}$ da + praesens wobec $2 \mathrm{z}$ bezokolicznikiem i podobnie po czasownikach ruchu: 14 zdań z da + praesens i 1 zdanie z bezokolicznikiem). Na częstsze użycie bezokolicznika po czasownikach modalnych, w czasie, gdy w pozostałych przebadanych utworach tego okresu sytuacja jest odwrotna, może wpływać pochodzenie pisarza (zachodnia Bośnia przy granicy z Chorwacją).

Reprezentantem powojennej prozy w literaturze serbskiej jest między innymi Dobrica Ćosić, urodzony w centralnej Serbii (we wsi Velika Drenova), który swoją bogatą karierę polityczną zwieńczył prezydenturą ${ }^{2}$ w latach 1992-1993. Na potrzeby badania przeanalizowano jego powieść Koreni z 1954 roku. Analiza utworu ukazuje wyraźną tendencję autora do korzystania z konstrukcji osobowej we wszystkich analizowanych kontekstach. Po czasownikach modalnych użycie bezokolicznika jest na poziomie 10\% (401 zdań z konstrukcją da + praesens, $46 \mathrm{z}$ bezokolicznikiem). Po czasownikach o niepełnym znaczeniu želeti, smeti, umeti - wyekscerpowano 72 użycia z konstrukcją $d a+$ praesens i tylko 1 zdanie $\mathrm{z}$ bezokolicznikiem, po czasownikach fazowych wystąpiły wyłącznie 22 zdania $\mathrm{z} d a+$ praesens, podobnie po czasownikach ruchu: 4 zdania $\mathrm{z}$ konstrukcją $d a+$ praesens.

Odmiennie wygląda badany problem w prozie Borislava Pekicia, urodzonego w Podgoricy w Czarnogórze w roku 1930, od 1945 roku mieszkającego w Belgradzie, który opuścił w roku 1971, udając się na emigrację do Londynu. Analizie poddano powieść - epos Atlantida, wydaną w roku 1988 w Zagrzebiu. Badanie wykazało 82\% użyć bezokolicznika po czasownikach modalnych (315 zdań z konstrukcją $d a+$ praesens, wobec aż 1435 zdań z bezokolicznikiem). Po czasownikach o niepełnym znaczeniu želeti, smeti, umeti - wyekscerpowano 65 użyć konstrukcji $\mathrm{z}$ da + praesens i tylko 19 zdań $\mathrm{z}$ bezokolicznikiem. Po czasownikach fazowych $6 \mathrm{zdań} \mathrm{z} d a+$ praesens i $12 \mathrm{z}$ bezokolicznikiem. Po czasownikach ruchu w dwóch wynotowanych zdaniach wystąpiła konstrukcja $d a+$ praesens.

Ostatnim utworem poddanym analizie jest książka autora młodej generacji serbskich prozaików - Marko Vidojkovicia, urodzonego w roku 1975

2 Pierwszy prezydent Federalnej Republiki Jugosławii (1992-1993). 
w Belgradzie. Powieść Kandže wydana w 2004 roku cechuje kolejne zwiększenie stosowania konstrukcji da + praesens w kontekstach po czasownikach modalnych - wystąpiła ona w 93\% wyekscerpowanych zdań (180 zdań z konstrukcją $d a+$ praesens i 14 zdań z bezokolicznikiem). Także w pozostałych kontekstach wystąpiła wyraźna przewaga użycia konstrukcji z da + praesens. Po czasownikach želeti, smeti, umeti przewaga przykładów z konstrukcją osobową jest wyraźna (16 zdań z konstrukcją da + praesens i tylko jedno zdanie z bezokolicznikiem). W kontekście czasowników oznaczających rozpoczęcie bądź zakończenie jakieś czynności lub stanu wystąpiły wyłącznie formy osobowe (82 przykłady), także po czasownikach ruchu wystąpiło 16 zdań - wszystkie $\mathrm{z}$ konstrukcją $d a+$ praesens.

Stosunek badanych konstrukcji w analizowanych kontekstach przedstawia poniższa tabela.

Tab. 1. Użycie bezokolicznika w analizowanych wyrażeniach polipredykatywnych

\begin{tabular}{|c|c|c|c|c|c|c|}
\hline \multirow[b]{2}{*}{ Autor } & \multirow[b]{2}{*}{ Tytuł } & \multirow[b]{2}{*}{ Rok } & \multicolumn{4}{|c|}{ Kontekst } \\
\hline & & & 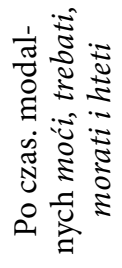 & 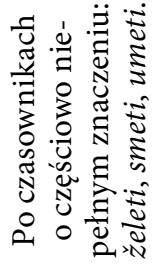 & 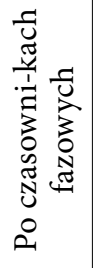 & 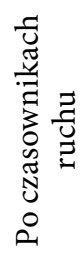 \\
\hline Sveti Sava & Sabrana Dela & $1200-1225$ & $71 \%$ & $58 \%$ & $100 \%$ & $100 \%$ \\
\hline Dositej Obradović & Život i i priključenija & 1783,1788 & $97 \%$ & $65 \%$ & $100 \%$ & $100 \%$ \\
\hline Đura Jakšić & Proza & 1849 & $85 \%$ & $70 \%$ & $100 \%$ & $33 \%$ \\
\hline Jakov Ignjatović & Večiti mladoženja & 1878 & $82 \%$ & $94 \%$ & $100 \%$ & $0 \%$ \\
\hline Laza Lazarević & Pripovetke & $1882-1890$ & $64 \%$ & $67 \%$ & $57 \%$ & $0 \%$ \\
\hline \multirow{2}{*}{ Borisav Stanković } & Božiji ljudi & 1902 & $2,4 \%$ & $0 \%$ & $0 \%$ & $0 \%$ \\
\hline & Nečista krv & 1910 & $29 \%$ & $27 \%$ & $26 \%$ & $0 \%$ \\
\hline Miloš Crnjanski & Seobe & 1927 & $32 \%$ & $0 \%$ & $8 \%$ & $0 \%$ \\
\hline Ivo Andrić & Na Drini ćuprija & 1945 & $30 \%$ & $4 \%$ & $100 \%$ & - \\
\hline Branko Ćopić & Orlovi rano lete & 1959 & $70 \%$ & - & $12 \%$ & $7 \%$ \\
\hline Dobrica Ćosić & Koreni & 1954 & $10 \%$ & $1,4 \%$ & $0 \%$ & $0 \%$ \\
\hline Borislav Pekić & Atlantida & 1988 & $82 \%$ & $23 \%$ & $67 \%$ & $0 \%$ \\
\hline Marko Vidojković & Kandže & 2004 & $7 \%$ & $6 \%$ & $0 \%$ & $0 \%$ \\
\hline
\end{tabular}


Analiza powyższych 13 utworów literackich, w miarę poruszania się po dziełach coraz bliższych współczesności, potwierdza stopniowy zanik bezokolicznika we wszystkich kontekstach. Jedynie utwory Borislava Pekicia (z roku 1988) i Branka Ćopicia (z roku 1959) wykazują mniejsze tempo zmiany. Można to tłumaczyć pochodzeniem obu pisarzy: Pekić pochodzi z Czarnogóry, a Ćopić z zachodniej Bośni. Ponadto utwór Pekicia Orlovi rano lete jest pisany w dialekcie jekawskim (a druga jego powieść Atlantida - odmianą ekawską).

Użycie bezokolicznika jest niemal powszechne do przełomu XIX i XX wieku. W wieku XX konstrukcja ze spójnikiem da i formą osobową czasownika wypiera bezokolicznik już we wszystkich badanych kontekstach.

Należy jednak pamiętać, że stosunkowo częste zastępowanie bezokolicznika osobową konstrukcją analityczną $d a+$ praesens w zdaniach polipredykatywnych nie oznacza jeszcze, że zanik bezokolicznika w języku serbskim jest faktem. W innych kontekstach np. po formach predykatywnych šteta, muka, lako, korisno, wprowadzających i akcentujących bezosobowość, nieokreśloność czy ogólność, zwykle stosuje się bezokolicznik np. Korisno je piti vodu.

Obie konstrukcje, bezokolicznik i analityczna konstrukcja da + praesens, są i na przestrzeni czasu były, w języku serbskim równorzędne i równoznaczne. Różnica polega na ich regionalnym i/lub indywidualnym zastosowaniu. Pogranicza Serbii, Kosowa i Macedonii, (jak i tereny pograniczne Grecji, Macedonii i Albanii) to areał, na którym wciąż dochodzi do przenikania konstrukcji językowych i procesów językowych. Nie dziwi więc zanik użycia konstrukcji bezokolicznikowej w dziełach Borisava Stankovicia, urodzonego właśnie we Vranju, miejscu, które obecnie na takim pograniczu języka serbskiego, albańskiego i bułgarskiego się znajduje. Miasto to także wcześniej było strategicznym miejscem, w którym krzyżowały się ważne szlaki handlowe i kulturowe. Do 1878 roku Vranje znajdowało się we władaniu Imperium Osmańskiego. Miasto było wielojęzyczne. Swoista „bałkańskość” tego miejsca jest wyraźnie widoczna u Stankovicia - tak na poziomie języka, jak i tematów podejmowanych w dziełach przez pisarza. W miejscowym dialekcie Vranja bezokolicznika nie używa się w ogóle.

Biorąc zatem pod uwagę zróżnicowanie geograficzne występowania badanych form na terenie języka serbskiego, sensowne wydaje się ograniczenie porównania do autorów pochodzących z północy oraz z Szumadii. Jest to faktyczny obszar kształtowania się współczesnego serbskiego standardu ${ }^{3}$. Odrzucamy zatem teksty z południowej Serbii, Bośni i Czarnogóry. Tak więc

3 Mimo deklaracji o normie opartej na dialekcie wschodniohercegowińskim. 
poniższa tabela, mimo skromności materiału, jak się zdaje, lepiej odzwierciedla proces utraty bezokolicznika w serbskim języku literackim:

Tab. 2. Występowanie bezokolicznika w konstrukcjach polipredykatywnych w tekstach literackich z północnej i środkowej Serbii

\begin{tabular}{|c|c|c|c|c|c|c|}
\hline \multirow[b]{2}{*}{ Autor } & \multirow[b]{2}{*}{ Tytuł } & \multirow[b]{2}{*}{ Rok } & \multicolumn{4}{|c|}{ Kontekst } \\
\hline & & & 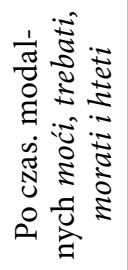 & 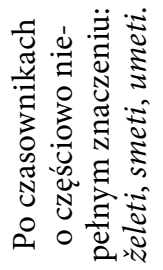 & 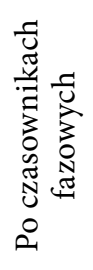 & 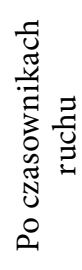 \\
\hline Dositej Obradović & Život i i priključenija & 1783,1788 & $97 \%$ & $65 \%$ & $100 \%$ & $100 \%$ \\
\hline Đura Jakšić & Proza & 1849 & $85 \%$ & $70 \%$ & $100 \%$ & $33 \%$ \\
\hline Jakov Ignjatović & Večiti mladoženja & 1878 & $82 \%$ & $94 \%$ & $100 \%$ & $0 \%$ \\
\hline Laza Lazarević & Pripovetke & $1882-1890$ & $64 \%$ & $67 \%$ & $57 \%$ & $0 \%$ \\
\hline Miloš Crnjanski & Seobe & 1927 & $32 \%$ & $0 \%$ & $8 \%$ & $0 \%$ \\
\hline Dobrica Ćosić & Koreni & 1954 & $10 \%$ & $1,4 \%$ & $0 \%$ & $0 \%$ \\
\hline Marko Vidojković & Kandže & 2004 & $7 \%$ & $6 \%$ & $0 \%$ & $0 \%$ \\
\hline
\end{tabular}

Mając na uwadze różne nacechowanie bałkanizmami poszczególnych dialektów serbskich, sensowne wydaje się odrębne badanie tekstów z poszczególnych regionów Serbii. Z drugiej jednak strony język literacki, siłą rzeczy, kumuluje w sobie cechy różnych regionów, a poszczególni pisarze, jak wskazują ich życiorysy literackie, łatwo zmieniają regionalne warianty językowe, w zależności od tego, w jakim miejscu kraju ostatecznie osiadają - między innymi przechodzą z wersji jekawskiej na ekawską lub na odwrót. Często cechy regionalne związane z pochodzeniem pisarza, w ogóle nie ujawniają się w jego pisarstwie. W związku z taką szczególną sytuacją, w jakiej kształtuje się serbski standard, każda decyzja dotycząca doboru materiału będzie decyzją kontrowersyjną.

Pomimo powyższych trudności sądzę, że na podstawie przeprowadzonego porównania można stwierdzić, iż proces stopniowego zaniku bezokolicznika widoczny jest od początku istnienia serbskiego piśmiennictwa. Pod koniec XIX wieku nabrał wyraźnego przyspieszenia. Można uznać, że współcześnie bezokolicznik w języku serbskim występuje śladowo. 


\section{BIBLIOGRAFIA}

Andrić, I. (2009). Na Drini Ćuprija. Beograd: Antologija Srpske Književnosti, Učiteljski Fakultet Univerziteta u Beogradu. Pobrano 19 lutego 2013, z www.ask.rs

Antologija Srpske Književnosti. (2009). Pobrano z www.ask.rs

Belić, B. (2005). The infinitive is difficult to lose: What governs variation of complements in unique control in Serbian. The Slavic and East European Language Resource Center, (6).

Brian, J. (1980). A new convergence concerning the Balkan loss of the infinitive. Indogermanische Forschungen, 85, 176-187.

Brian, J. (1981). The Balkan infinitive loss - some methodological problems. W H. Aronson \& B. Darden (Red.), Studies in Balkan linguistics to honor Eric P. Hamp on his sixtieth birthday (ss. 300-308). (Folia Slavica 4.2-3)

Brian, J. (1983). The synchrony and diachrony of the Balkan infinitive: A study in areal, general, and historical linguistics. Cambridge: Cambridge University Press. (Cambridge Studies in Linguistics, Supplementary Series)

Crnjanski, M. (2009). Seobe (T. 1). Beograd: Antologija Srpske Književnosti, Učiteljski Fakultet Univerziteta u Beogradu. Pobrano 5 lutego 2013, z www.ask.rs

Ćopić, B. (2009). Orlovi rano lete. Beograd: Antologija Srpske Književnosti, Učiteljski Fakultet Univerziteta u Beogradu. Pobrano 19 lutego 2013, z www.ask.rs

Ćosić, D. (2009). Koreni. Beograd: Antologija Srpske Književnosti, Učiteljski Fakultet Univerziteta u Beogradu. Pobrano 6 marca 2013, z www.ask.rs

Demiraj, S. (1970). De la perte de l'infinitif albanais. Studia Albanica, 7, 125-130.

Demiraj, S. (1994). Gjuhësi ballkanike. Skopje: Balkanska Lingvistika. Logos-A.

Đukanović, V. (1994). Glagoli trebati i valjati i njihova infinitivno/prezentska dopuna. W: Naučni sastanak slavista u Vukove dane (22/2, ss. 119-126). Beograd.

Ignjatović, J. (2009). Večiti Mladoženja. Beograd: Antologija Srpske Književnosti, Učiteljski Fakultet Univerziteta u Beogradu. Pobrano 19 lutego 2013, z www.ask.rs

Ivić, M. (1970). O upotrebi glagolskih vremena u zavisnoj rečenici: prezent u rečenici s veznikom da. Zbornik Matice srpske za filologiju i lingvistiku, 13(1), 43-55.

Ivić, M. (1972). Problematika srpskohrvatskog infinitiva. Zbornik Matice srpske za filologiju i lingvistiku, 15(2), 115-138.

Jakšić, Đ. (2009). Proza. Beograd: Antologija Srpske Književnosti, Učiteljski Fakultet Univerziteta u Beogradu. Pobrano 5 lutego 2013, z www.ask.rs

Klajn, I. (2005). Gramatika srpskog jezika. Beograd: Zavod za udžbenike i nastavna sredstva.

Lazarević, L. (2009). Pripovetke. Beograd: Antologija Srpske Književnosti, Učiteljski Fakultet Univerziteta u Beogradu. Pobrano 6 marca 2013, z www.ask.rs

Obradović, D. (2009). Život i Priključenija. Beograd: Antologija Srpske Književnosti, Učiteljski Fakultet Univerziteta u Beogradu. Pobrano 5 lutego 2013, z www.ask.rs

Pekić, B. (1988). Atlantida. Zagreb: Znanje. 
Polański K. (red.) (2003), Encyklopedia językoznawstwa ogólnego, Wrocław.

Sandfeld, K. (1930). Linguistique balkanique: Problèmes et résultats. Paris: Librairie ancienne. Honoré Champion. (Collection linguistique publiée de la Société de Linguistique de Paris, 31) (Pierwsze wydanie - Kopenhaga 1926: Balkanfilologien: en oversigt over dens resultater og problemer).

Sawicka, I. (2009). O geografii fonetycznej Europy: Na podstawie fonetyki południowo-wschodniej Europy. Linguistica Copernicana, 1(1), 199-222.

Schaller, H. (1975). Die Balkansprachen: Eine Einführung in die Balkanphilogie. Heidelberg: Carl Winter Universitätsverlag.

Stanković, B. (2009a). Božji Ljudi. Beograd: Antologija Srpske Književnosti, Učiteljski Fakultet Univerziteta u Beogradu. Pobrano 5 lutego 2013, z www.ask.rs

Stanković, B. (2009b). Nečista Krv. Beograd: Antologija Srpske Književnosti, Učiteljski Fakultet Univerziteta u Beogradu. Pobrano 6 marca 2013, z www.ask.rs

Sveti Sava. (2009). Sabrana Dela. Beograd: Antologija Srpske Književnosti, Učiteljski Fakultet Univerziteta u Beogradu. Pobrano 5 lutego 2013, z www.ask.rs

Vidojković, M. (2004). Kandže. Beograd: Samizdat B92.

Zvekić-Dušanović, D. (2001). Infinitiv u srpskom i mađarskom jeziku. Zbornik Matice srpske za filologiju i lingvistiku, 44(br. 1-2), 25-95.

Асенова, П. (2002). Балканско езикознание: Основни проблеми на балканския езиков съюз. Велико Търново.

Брборић, П., Ивић, П., Клајн, И., \& Пешикан, М. (2007). Српски Језички Приручник. Београд: Београдска књига.

Лопашов, Ю. А. (1990). Новогреческий язык. W А. Десницкая (Red.), Основы балканского языкознания (ч. 1, ss. 9-45). Ленинград: „Наука”.

Станојчић, Ж., \& Поповић, Љ. (1995). Граматика српског језика: Уибеник за I, II, III и IV разред средюе школе. Београд.

Стевановић, М. (1953). Напоредна употреба инфинитива и презента са свезицом да. Наш језик, 5(3-4), 85-102.

\section{BIBLIOGRAPHY}

\section{(TRANSLITERATION)}

Andrić, I. (2009). Na Drini Ćuprija. Beograd: Antologija Srpske Književnosti, Učiteljski Fakultet Univerziteta u Beogradu. Retrieved February 19, 2013, from www.ask.rs

Antologija Srpske Književnosti. (2009). Retrieved from www.ask.rs

Asenova, P. (2002). Balkansko ezikoznanie: Osnovni problemi na balkanskiia ezikov sŭiuz. Veliko Tŭrnovo. 
Belić, B. (2005). The infinitive is difficult to lose: What governs variation of complements in unique control in Serbian. The Slavic and East European Language Resource Center, (6).

Brborić, P., Ivić, P., Klajn, I., \& Pešikan, M. (2007). Srpski Jezički Priručnik. Beograd: Beogradska knjiga.

Brian, J. (1980). A new convergence concerning the Balkan loss of the infinitive. Indogermanische Forschungen, 85, 176-187.

Brian, J. (1981). The Balkan infinitive loss - some methodological problems. In H. Aronson \& B. Darden (Eds.), Studies in Balkan linguistics to honor Eric P. Hamp on his sixtieth birthday (pp. 300-308). (Folia Slavica 4.2-3)

Brian, J. (1983). The synchrony and diachrony of the Balkan infinitive: A study in areal, general, and historical linguistics. Cambridge: Cambridge University Press. (Cambridge Studies in Linguistics, Supplementary Series)

Crnjanski, M. (2009). Seobe (Vol. 1). Beograd: Antologija Srpske Književnosti, Učiteljski Fakultet Univerziteta u Beogradu. Retrieved February 5, 2013, from www.ask.rs

Ćopić, B. (2009). Orlovi rano lete. Beograd: Antologija Srpske Književnosti, Učiteljski Fakultet Univerziteta u Beogradu. Retrieved February 19, 2013, from www.ask.rs

Ćosić, D. (2009). Koreni. Beograd: Antologija Srpske Književnosti, Učiteljski Fakultet Univerziteta u Beogradu. Retrieved March 6, 2013, from www.ask.rs

Demiraj, S. (1970). De la perte de l'infinitif albanais. Studia Albanica, 7, 125-130.

Demiraj, S. (1994). Gjuhësi ballkanike. Skopje: Balkanska Lingvistika. Logos-A.

Đukanović, V. (1994). Glagoli trebati i valjati i njihova infinitivno/prezentska dopuna. In Naučni sastanak slavista u Vukove dane (22/2, pp. 119-126). Beograd.

Ignjatović, J. (2009). Večiti Mladoženja. Beograd: Antologija Srpske Književnosti, Učiteljski Fakultet Univerziteta u Beogradu. Retrieved February 19, 2013, from www.ask.rs

Ivić, M. (1970). O upotrebi glagolskih vremena u zavisnoj rečenici: prezent u rečenici s veznikom da. Zbornik Matice srpske za filologiju i lingvistiku, 13(1), 43-55.

Ivić, M. (1972). Problematika srpskohrvatskog infinitiva. Zbornik Matice srpske za filologiju i lingvistiku, 15(2), 115-138.

Jakšić, Đ. (2009). Proza. Beograd: Antologija Srpske Književnosti, Učiteljski Fakultet Univerziteta u Beogradu. Retrieved February 5, 2013, from www.ask.rs

Klajn, I. (2005). Gramatika srpskog jezika. Beograd: Zavod za udžbenike i nastavna sredstva.

Lazarević, L. (2009). Pripovetke. Beograd: Antologija Srpske Književnosti, Učiteljski Fakultet Univerziteta u Beogradu. Retrieved March 6, 2013, from www.ask.rs

Lopashov, I. A. (1990). Novogrecheskiǔ iazyk. In A. Desnitskaia (Ed.), Osnovy balkanskogo iazykoznaniia (Part 1, pp. 9-45). Leningrad: „Nauka”.

Obradović, D. (2009). Život i Priključenija. Beograd: Antologija Srpske Književnosti, Učiteljski Fakultet Univerziteta u Beogradu. Retrieved February 5, 2013, from www.ask.rs

Pekić, B. (1988). Atlantida. Zagreb: Znanje.

Polański K. (red.) (2003), Encyklopedia językoznawstwa ogólnego, Wrocław. 
Sandfeld, K. (1930). Linguistique balkanique: Problèmes et résultats. Paris: Librairie ancienne. Honoré Champion. (Collection linguistique publiée de la Société de Linguistique de Paris, 31) (First published in Copenhagen in 1926 as Balkanfilologien: en oversigt over dens resultater og problemer)

Sawicka, I. (2009). O geografii fonetycznej Europy: Na podstawie fonetyki południowo-wschodniej Europy. Linguistica Copernicana, 1(1), 199-222.

Schaller, H. (1975). Die Balkansprachen: Eine Einführung in die Balkanphilogie. Heidelberg: Carl Winter Universitätsverlag.

Stanković, B. (2009a). Božji Ljudi. Beograd: Antologija Srpske Književnosti, Učiteljski Fakultet Univerziteta u Beogradu. Retrieved February 5, 2013, from www.ask.rs

Stanković, B. (2009b). Nečista Krv. Beograd: Antologija Srpske Književnosti, Učiteljski Fakultet Univerziteta u Beogradu. Retrieved March 6, 2013, from www.ask.rs

Stanojčić, Ž., \& Popović, L. (1995). Gramatika srpskog jezika: Udžbenik za I, II, III i IV razred srednje škole. Beograd.

Stevanović, M. (1953). Naporedna upotreba infinitiva i prezenta sa svezicom da. Naš jezik, 5(3-4), 85-102.

Sveti Sava. (2009). Sabrana Dela. Beograd: Antologija Srpske Književnosti, Učiteljski Fakultet Univerziteta u Beogradu. Retrieved February 5, 2013, from www.ask.rs

Vidojković, M. (2004). Kandže. Beograd: Samizdat B92.

Zvekić-Dušanović, D. (2001). Infinitiv u srpskom i mađarskom jeziku. Zbornik Matice srpske za filologiju i lingvistiku, 44(br. 1-2), 25-95.

\section{Zanikanie bezokolicznika w języku serbskim. Wstępne rozpoznanie zagadnienia}

Artykuł dotyczy procesu zanikania bezokolicznika w języku serbskim i stopniowego zastępowania go konstrukcją $d a+$ praesens. Materiał, który posłużył do analizy, stanowi przekrój piśmiennictwa ograniczonego do rdzennych terenów serbskich: wychodzi już od czasów św. Sawy, którego teksty jako jedne z pierwszych są powszechnie dostępne. Ostatni przeanalizowany tekst pochodzi z początku XXI wieku. Materiał przebadano w kontekstach, w których obie konstrukcje są w pełni równoznaczne.

Słowa kluczowe: serbski język; bezokolicznik; konstrukcja $d a+$ praesens 


\section{The Loss of the Infinitive in Serbian. Preliminary Issue}

The article concerns the loss of the infinitive in Serbian literary language and its gradual replacement by the construction $d a+$ praesens. The analyzed material consists of Serbian and Serbo-Croatian literature and goes from the Saint Sava's texts - these are the first widely available texts of Serbian. The last text analyzed comes from the beginning of XXI century. The process of the loss of infinitive has been checked in the contexts in which it is possible to replace the infinitive form by the structure $d a+$ verb in the present tense without changing the meaning.

Keywords: Serbian; infinitiv; the utterance $d a+$ praesens

\section{Notka o autorze}

Artur Karasiński (artur.karasinski@gmail.com) - adiunkt na Uniwersytecie Mikołaja Kopernika w Toruniu, bałkanolog, slawista. Zajmuje się słowotwórstwem albańskim. Członek Bałkanologicznej Komisji Językoznawczej przy Międzynarodowym Komitecie Slawistów.

Artur Karasiński, PhD (artur.karasinski@gmail.com) - linguist, lecturer at the Nicolas Copernicus University in Toruń. Research interests: Slavic and Balkan languages. His main reseach field is Albanian word formation. Member of the Balkan Linguistic Commission of the International Committee of Slavists. 